\title{
Cash Waqf: An Innovation in Mobilizing the Potential of Waqf
}

\author{
Moh Fakhrurozi ${ }^{1}$, Warsiyah ${ }^{2}$, Noorikha Pandayahesti Saputeri ${ }^{3}$, Aditya Pratama ${ }^{4}$ \\ \{rozi_pkbtuba@yahoo.co.id ${ }^{1}$ \} \\ Study program of Islamic banking, Faculty of Islamic Religion, University of Muhammadiyah Lampung, \\ Lampung, Indonesia ${ }^{1,2,3,4}$
}

\begin{abstract}
This study aims to determine innovations in the digital mobilization of cash waqf potential. The method used in this research is descriptive qualitative. To mobilize waqf, the Indonesian Waqf Education Foundation (YEWI) pioneered the formation of the ambassador Waqf as an institution that organizes training \& certification of waqf consultants. Waqf ambassadors are expected to be able to educate the public to do charity digitally. The position of the ambassador for waqf is between Nazhir and Wakif. In managing cash waqf, Nazhir must cooperate with the LKS-PWU (Sharia Financial Institution Cash Waqf Recipient). Cash waqf can be made with a relatively small amount of money and collected together to meet the requirements for issuing a certificate from the LKS PWU. The profit-sharing from the waqf investment is used to finance the activities programmed by Nazir. The results of cash waqf can be used to create jobs in order to reduce unemployment, help business capital for MSMEs in need, guidance, development of education and assistance with education costs, development of public infrastructure. Innovations in mobilizing the potential for waqf need to be socialized because it can be done digitally and anytime without regional boundaries.
\end{abstract}

Keywords: Cash waqf, Innovation, Waqf ambassador

\section{Introduction}

Islamic economics is a study of human behavior to fulfill their needs in order to maximize fallah, namely happiness in the world and the hereafter [11]. This science examines how to preserve entire economic resources or production factors to maintain their wealth and income distribution, not focusing on one particular group but throughout humanity therefore, there are no economic difficulties that hinder humans to worship Allah SWT. This needs to be underlined because the economy is basically only a tool for humans to carry out their main purpose in life.

There are two ways of transfer of economic resources to achieve prosperity: First, commercially, which occurs through economic activities. Second, it occurs socially in the form of assistance such as zakat, infaq, waqf, and shadaqah. The existence of these two transfers of economic resources is a potential for the ummah because not everyone is able to perform economic processes and activities. For those who are healthy, physically strong, and have the opportunity, they can acquire their source of life from economic activities. However, for others who cannot afford it, Islam protects it with social-economic security insurance in the form of zakat, donations, and shadaqah [14]. These forms of handover must be managed and utilized proportionally. 
Zakat is mandatory whereas infaq, alm, and waqf are Sunnah. Waqf referring to authentic hadith can be categorized into infaq. In other words, the concept of infaq includes waqf. But the difference lies in the perpetuity of the benefits. In its history, waqf has played a pivotal role in supporting the establishment of Islamic social institutions [3].

The absorption of waqf potential in Indonesia is far from what was expected, coupled with its management which is still at a non-productive level. In $2016,75 \%$ of waqf assets were still used for the construction of mosques, $14 \%$ for education, $5 \%$ for funerals and $6 \%$ for other uses. Furthermore, the potential for cash waqf in Indonesia reaches Rp. 180 trillion. Then from that amount of Rp. 180 trillion, as much as Rp. 400 billion has been realized. Meanwhile, in 2019, BWI targets the realization of cash waqf to attain IDR 800 billion [4].

Cash waqf is waqf made by a person, group, institution, or legal entity in the form of cash. The principle that must be adhered to is that the value of cash waqf must be guaranteed for its sustainability. Cash waqf must be invested in productive activities therefore, the return of the waqf value can be generated and utilized for the benefit of the recipient.

Currently, many Islamic philanthropic institutions are active in collecting cash waqf. To mobilize it, the Indonesian Waqf Education Foundation (YEWI) has a program to produce professional waqf consultants or Waqf Ambassadors who can assist people comprehend waqf and become a waqif simply and affordably. Waqf ambassadors are trained to use digital facilities with programs and socialization materials that are ready to be performed. The position of Waqf Ambassador is between Nazhir and Waqif. Nazir is the recipient of waqf property from waqif to be managed and developed according to its purpose whereas waqif is the party who conducts waqf. In managing cash waqf, Nazhir must cooperate with the LKS-PWU (Sharia Financial Institution-Cash Waqf Recipient). As of August 2020, in Indonesia, there are 22 LKS-PWU registered according to the Minister of Religion's decree. In addition to functioning as the Cash Waqf Pledge Deed Officer (PPAIW), LKS PWU is also the party in charge of providing instruments or products for cash waqf management for nazirs.

Cash waqf opens opportunities for people to do charity Jariyah. It can be made with a relatively small amount of money and collected together in order to meet the requirements for issuing a certificate from the LKS- PWU. The profit from this waqf investment is used to finance the activities programmed by Nazir. Nazir has a program of activities that have been determined and socialized to the community. In social media, there are currently many advertisements about appeals and suggestions for waqf such as waqf al Quran, waqf building mosques, waqf construction of Islamic boarding schools and others.

The Indonesian Waqf Education Foundation (YEWI) has collaborated with LKS PWU, namely Bank BTN Syariah in formulating the process of cash waqf management. Collaboration with the Directorate of Zakat \& Waqf Empowerment at the Directorate General of Islamic Community Guidance of the Ministry of Religion of the Republic of Indonesia, the Indonesian Waqf Board (BWI), nazhir cash waqf namely DMI Yogyakarta Special Region, BMT Muda East Java, BMT GEMI, BMT Artha Amanah Sanden, BMT Dana Insani, BMT Bina Ihsanul Firi, Askar Kauny Foundation and the Non-Islamic Banking Financial Industry such as sharia life insurance. This paper will highlight YEWI's performance as a promotional agent and educate the public on the potential absorption of cash waqf in Indonesia. 


\section{Literature Review}

Indonesia is the highest Muslim population in the world hence, it is natural that there are regulations related to the distribution of the Islamic economy including waqf. This is supported by a report published by the Charities Aid Foundation (CAF) where Indonesia was named the most generous country according to the 2018 world giving index. Islamic philanthropy institutions that rise in Indonesia include Dompet Dhuafa (DD), Rumah Zakat Indonesia (RZI), Dompet Peduli Umat-Daarut Tauhid (DPU-DT), LazisMu, Al-Azhar Care, Baitul Maal Hidayatullah (BMH), Global Waqf, Indonesian Mosque Council (DMI).

The practice of cash waqf in Indonesia is based on Government Regulation (PP) Number 42 of 2006 which was later amended in Government Regulation (PP) Number 25 of 2018 which contains matters concerning cash waqf, Nazhir, and Islamic financial institutions. The Ministry of Religion has established 22 Islamic financial institutions as LKS-PWU.

There are four pillars of waqf, namely: (1) people who conduct waqf, (2) objects that are donated, (3) people who receive waqf benefits, (4) pledge waqf [8] while in article 6 of the Waqf Law which is the legal basis for the implementation of waqf, in addition to the four pillars in implementing waqf there are two additional elements namely the allotment of waqf assets and a period.

More specifically, the Indonesian Ulama Council (MUI) issued a Fatwa on Cash Waqf on May 11, 2002, which stated that: (1) Cash Waqf (Waqf al-Nuqud) is waqf made by a person, group of people, institution or legal entities in cash; (2) included in the definition of money are securities; (3) cash waqf is jawaz (allowed); (4) cash waqf may only be distributed and used for things that are permitted in Islam; (5) The preservation of the principal value of Cash Waqf must be guaranteed, not to be sold, granted and/ or inherited. The rigidity of the rules regarding waqf is a derivative of the essence of Islamic economics which views property as a mandate that is used as a means of worship, not as a goal [5]. The process of cash waqf describe at Figure 1.

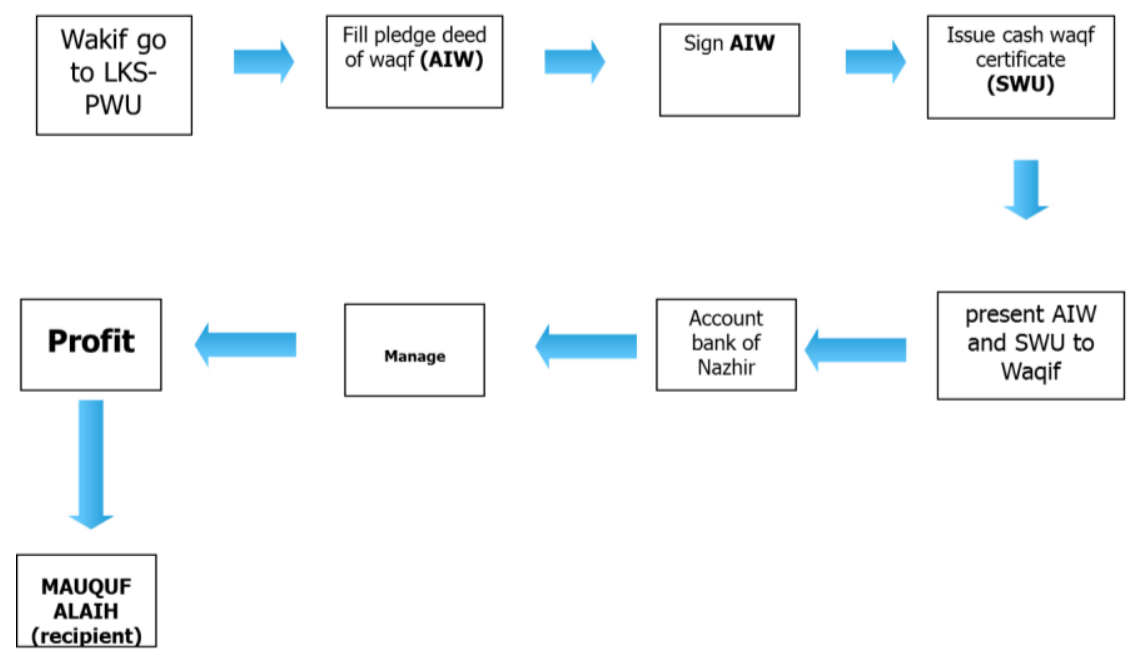

Fig. 1. Cash Waqf Process 
Waqf has been known as an instrument of worship and is usually in the form of immovable objects (land) designated for education, places of worship and graves. Land prices are relatively expensive and limited, the rich can do it. Money is one of the movable objects and requires different management from immovable property. The process of implementing cash waqf is in accordance with the mechanism determined by the Indonesian Waqf Board (BWI). These mechanisms include: 1) prospective waqif can implement cash waqf by transferring money to the designated LKS- PWU; 2) prospective waqif can deposit cash waqf at any time; 3) prospective waqif candidate is given a guarantee that the funds that have been donated are guaranteed immortality.

\section{Method}

The method used in this research is a framework for writing the results of thought (research library). Descriptively explain and analyze the concept of cash waqf, the potential of cash waqf, and stipulate the strategy for developing cash waqf in Indonesia. In order to obtain facts and correct interpretations, the qualitative-descriptive approach is used which emphasizes the analysis more on the deductive and inductive inference processes and conducts analysis only up to the level of description.

\section{Results and Discussion}

In Indonesia, the potential for cash waqf is enormous. Every Muslim able to perform waqf with a relatively small amount of money. It becomes a great force in driving the economy. To mobilize the potential for waqf, it is necessary to have an active role from Nazhir and the Waqf Bureau, therefore, the enforcement of waqf funds and the number of waqif escalate.

However, in terms of awareness, public knowledge regarding the terminology of contemporary waqf such as cash waqf is limited. In terms of research, development and technology, waqf institutions are still in the stage of developing research and using technology for collection and management

The 2020 Waqf Literacy Index report issued by the Indonesian Waqf Board can be an indicator for stakeholders in making decisions. Of the 32 provinces sampled, only four provinces showed an intermediate score, meaning that the majority of Muslims do not understand or even have heard of waqf at all. The index also revealed that the two main reasons respondents chose the Nadzir Institution were the aspects of accountability and transparency, as well as accessibility, $45 \%$ of respondents, chose to carry out their waqf to nazir institutions, while $29 \%$ of respondents implemented their waqf through direct submission to mauquf alaih

The opportunity for digitalization in the context of socializing the waqf program is wide open. Indonesian internet penetration in 2020 is climbing, where internet users now 175.4 million or around $64 \%$ of the total population. From the same report, there are 160 million social media users where the most visited social media is Youtube followed by Facebook then Instagram WhatsApp, and Twitter respectively. The majority of internet users in Indonesia use cellphones or gadgets, especially mobile internet therefore, it is possible to integrate online payment systems (e-payment) with the effective collection and management of waqf assets based on online payments (e-payment). 
The digitization of waqf through the waqfraiser application will facilitate socialization and education to Muslims, including payment services and management of waqf funds. Information related to the program and distribution of waqf funds can also be done digitally via social media or the Nazir website. Hopefully, the accumulation of cash waqf and waqif trust increase, eventually the potential for cash waqf can be optimized.

Here we can visualize the central role that waqf institutions such as YEWI are trying to present. This institution has initiated the waqf ambassador program since 2014 and has produced human resources capable of marketing cash waqf programs to the public. This professional community regularly holds seminars on waqf which can be an alternative to an Islamic profession or business. The waqf ambassador network also helps promote the waqf program from Nazhir to the surrounding by conducting literacy studies with waqf stakeholders. Advocated by the quality of knowledge and credible insights, the waqf ambassadors have scattered throughout Indonesia.

Current waqf is not exclusive anymore, because it can be done by anyone at any time who intends to do it. Collective cash waqf can be made with a minimum of IDR.50.000 which can be transferred directly to Nazhir's account that has collaborated with YEWI, after reached IDR. $1,000,000$, which consists of cash waqf from several people, a Collective cash Waqf Certificate \& Collective cash Waqf Pledge Deed will be issued by LKS PWU Officials which will then be sent a digital file to the waqif to be printed \& stored as evidence of waqf. This whole process is inexpensive and convenient because waqif can use digital payments such as mBanking or iBanking. Moreover, cash waqf revenue can be used to create jobs that can reduce unemployment, business capital for MSMEs in need, education development, scholarship, public infrastructure development.

\section{Conclusion}

YEWI as an institution that produces waqf ambassadors is an accelerator in disseminating information and cash waqf education through digitization. The resources collected through cash waqf activities are relevant in overcoming the problem of poverty in Indonesia. The generosity that has become a tradition and continues to grow and develop from society need to mobilize and revitalize to gain wider benefits

\section{References}

[1] Badan Wakaf Indonesia. 2020. Laporan Hasil Survey Indeks Literasi Wakaf

[2] Charities Aid Foundation (CAF). 2018. World Giving Index 2018 A Global View of Giving Trend

[3] Fauzia, A., Prihatna, A., Helmanita, K., Al-Makassary, R.., Kamil, S., Alawiyah, T. 2005. Revitalisasi Filantropi Islam Studi Kasus Lembaga Zakat dan Wakaf di Indonesia, Jakarta: The Ford Foundation

[4] Haniah Lubis. Potensi dan Strategi Pengembangan Wakaf Uang di Indonesia. IBF: Islamic Business and Finance, Vol. 1, No.1, April 2020

[5] Latief, H., As'ad, S., Khasanah, M. 2015. Fleksibilitas Pemaknaan Wakaf Tunai di Indonesia: Studi terhadap Lembaga Filantropi dan Lembaga Keuangan. Jurnal Afkaruna, Vol. 11 Nomor 1, Juni 2015

[6] Hootsuite (We are Social). 2020. Indonesian Digital Report 2020

[7] Kementerian Perencanaan Pembangunan Nasional/ Badan Perencanaan Pembangunan Nasional. 2018. Masterplan Ekonomi Syariah Indonesia 2019-2024 Hasil Kajian Analisis Ekonomi Syariah di Indonesia 
[8] Kholis, Nur. 2009. Ikhtiar Memberdayakan Potensi WaKaf Secara Produktif Di Indonesia. Proceedings Simposium Nasional Sistem Ekonomi islam IV Yogyakarta 8-9 Oktober 2009

[9] Noor, R.A.G. 2013. Konsep Distribusi Dalam Ekonomi Islam. Yogyakarta: Pustaka Pelajar

[10] UU No.41 tahun 2004 Tentang Wakaf

[11] Pusat Pengkajian dan Pengembangan Ekonomi Islam (P3EI) Universitas Islam Indonesia. 2015. Ekonomi Islam, seventh edition, Raja Grafindo persada: Jakarta

[12] Peraturan Pemerintah (PP) Nomor 42 Tahun 2006 Tentang Pelaksanaan UU Nomor 41 Tahun 2004Tentang Wakaf

[13] Peraturan Pemerintah (PP) Nomor 25 Tahun 2018 Tentang Perubahan Peraturan Pemerintah (PP) Nomor 42 Tahun 2006 Tentang Pelaksanaan UU Nomor 41 Tahun 2004

[14] Sadeq, Abdul Hasan. 2004. Economic Development in Islam, Bangladesh: Islamic Foundation

[15] https://yewi.or.id 